\title{
Lymphocyte Adherence in Multiple Sclerosis
}

\author{
EFFECT OF ASPIRIN
}

\author{
Paula Dore-Duffy and Robert B. Zurier, Division of Rheumatic Diseases, \\ Department of Medicine, University of Connecticut Health Center, \\ Farmington, Connecticut 06032
}

\begin{abstract}
A B S T RACT Peripheral blood lymphocytes from multiple sclerosis (MS) patients form substantially greater numbers of rosettes with measles virusinfected human epithelial cells than do lymphocytes from healthy controls or from patients with other diseases. We have previously shown that prostaglandin $\mathrm{E}_{1}$-treated normal lymphocytes exhibit increased lymphocyte adherence, and thus behave like MS lymphocytes in this in vitro system. In this study we describe the effect of prostaglandin synthesis inhibition on lymphocyte adherence in both MS and control patients. Direct addition of aspirin or indomethacin to peripheral blood mononuclear cells from MS patients in vitro reduced lymphocyte adherence to control levels. Ingestion of therapeutic (anti-inflammatory) doses of aspirin ( $1 \mathrm{~g}, 4$ times daily for $2 \mathrm{~d}$ ) by MS patients resulted in reduction of lymphocyte adherence to levels seen in healthy controls. A single $325-\mathrm{mg}$ dose of aspirin did not reduce lymphocyte adherence. A dose-dependent reduction in lymphocyte adherence was observed after single doses ranging from $650 \mathrm{mg}$ to $1.3 \mathrm{~g}$; duration of the effect was directly related to the aspirin dose. These observations indicate that treatment of MS patients with aspirin profoundly influences adherence of their lymphocytes to measles virus-infected cells and suggest that the altered cellular response, which results in increased lymphocyte adherence in MS patients, may be mediated by a prostaglandin-sensitive mechanism.
\end{abstract}

\section{INTRODUCTION}

Lymphocytes from patients with multiple sclerosis $(\mathrm{MS})^{1}$ adhere in significantly greater numbers to

The study was conducted during Dr. Dore-Duffy's tenure as a Fellow of the National Multiple Sclerosis Society.

Received for publication 22 June 1978 and in revised form 6 November 1978.

${ }^{1}$ Abbreviations used in this paper: HEp-2, human epithelial; LAD, lymphocyte adherence determination(s); MS, multiple sclerosis. measles virus-infected cells than lymphocytes from healthy controls $(1,2)$. We have shown (3) that addition to peripheral blood mononuclear cells of prostaglandin $\mathrm{E}_{1}$ markedly increases lymphocyte adherence to human epithelial (HEp-2) cells persistently infected with measles virus. Thus, prostaglandin $\mathrm{E}_{1}$-treated normal lymphocytes behave like MS lymphocytes in this in vitro model of an immunological reaction. We therefore investigated further the possible role of prostaglandins in the cell-surface mechanisms responsible for increased lymphocyte adherence in MS. We have found that addition of aspirin in vitro to MS mononuclear cells, and ingestion of aspirin by MS patients reduces lymphocyte adherence to normal levels.

\section{METHODS}

Chemicals. Acetylsalicylic acid was purchased from Sigma Chemical Co., St. Louis, Mo. The acetylsalicylic acid used for in vivo studies was Bayer brand aspirin tablets (The Bayer Company, Division of Sterling Drug. Inc., N. Y., $325 \mathrm{mg}$ each) purchased from a local pharmacy.

Patients. Patients with a confirmed diagnosis of MS according to the criteria of Schumacher et al. (4) were studied with approval of their personal physicians. Healthy volunteers from the University of Connecticut Health Center staff and faculty, matched for age and sex, served as controls. Patients and control donors discontinued intake of all drugs $48 \mathrm{~h}$ before studies were initiated. Fasting blood samples were obtained between 7 and 9 a.m. Different patients and healthy donors were studied in each group of experiments.

Cell isolation. Heparinized venous blood was diluted with an equal volume of Hanks' balanced salt solution and the mononuclear-cell layer obtained by centrifugation on Ficoll- (Pharmacia Fine Chemicals Inc., Piscataway, N. J.) Hypaque (Winthrop Laboratories, New York) gradients (Lymphocyte-separating medium solution, Bionetics Laboratory Products, Litton Bionetics Inc., Kensington, Md.) as outlined by Böyum (5).

In vitro studies. Mononuclear cells were incubated $\left(37^{\circ} \mathrm{C}\right.$ for $15 \mathrm{~min}$ ) with $0.5 \mathrm{mM}$ acetylsalicylic acid of $30 \mu \mathrm{M}$ indomethacin in Hanks' balanced salt solution, then washed twice in Hanks' balanced salt solution. Cells were incubated $\left(37^{\circ} \mathrm{C}\right.$ for $\left.30 \mathrm{~min}\right)$ with measles virus-infected $\mathrm{HEp}-2$ cells. Greater than $94 \%$ of cells remained viable (trypan blue exclusion). The $\mathrm{pH}$ was monitored throughout each experiment. For studies of prostaglandin synthesis, mononuclear 
cells were seeded on $35-\mathrm{mm}$ plastic Petri dishes $\left(1 \times 10^{6}\right.$ cells/plate) and placed in tissue culture (RPMI 1640, $10 \%$ fetal calf serum) for $24 \mathrm{~h}$. Mononuclear cell supernates were recovered and frozen at $-70^{\circ} \mathrm{C}$.

In vivo studies. Subjects ingested $1 \mathrm{~g}$ of aspirin 4 times daily for $2 \mathrm{~d}$. Blood was obtained for lymphocyte-adherence studies before aspirin ingestion, and 10,12 , and $24 \mathrm{~h}$ after the final aspirin dose. In other studies, subjects ingested single doses of aspirin (from $325 \mathrm{mg}$ to $1.3 \mathrm{~g}$ ). Blood samples were taken before aspirin ingestion, and at intervals up to $24 \mathrm{~h}$ after aspirin ingestion.

Measles virus-infected cells. HEp-2 cells persistently infected with measles virus (Edmonston) exhibited virusspecific antigens by immunofluorescence and hemadsorption on more than $90 \%$ of the cells. Approximately $10^{2}-10^{3}$ plaqueforming units were released per milliliter every $24 \mathrm{~h}$. Because measles virus-specific antigen concentrations can vary (6), infected cells were monitored weekly by hemadsorption with rhesus monkey erythrocytes. Cultures were not used unless $90-95 \%$ of cells exhibited antigen. Cells were maintained in Eagle's minimum essential medium supplemented with $10 \%$ fetal calf serum.

Lymphocyte adherence determination (LAD). Monolayers of infected HEp-2 cells were dispersed with $0.54 \mathrm{mM}$ disodium ethylenediamine-tetra-acetate. Cells were washed three times in Hanks' balanced salt solution, $\mathrm{pH}$ 7.0-7.2. Lymphocytes $\left(1.5 \times 10^{6}\right)$ were incubated $\left(37^{\circ} \mathrm{C}\right.$ for $\left.30 \mathrm{~min}\right)$ with $1.5 \times 10^{5} \mathrm{HEp}-2$ cells in a final volume of $1 \mathrm{ml}$. Cells were centrifuged $(200 \mathrm{~g}$ for $3 \mathrm{~min})$, resuspended, and examined for lymphocyte adherence. A total of 250-300 HEp-2 cells were counted, and epithelial cells to which three or more lymphocytes had adhered were counted as positive. Lymphocyte adherence is expressed as the percentage of HEp-2 cells with three or more adherent lymphocytes (percent LAD).

Serum salicylate levels. Serum salicylate levels were determined by a modification of the Natelson colorimetric technique (7). Pooled human serum with a salicylate level of $25 \mathrm{mg} / \mathrm{dl}$ was used as a standard.

\section{RESULTS}

Effect of acetylsalicylic acid (in vitro) on lymphocyte adherence. Results of LAD are shown in Table I. In all experiments, MS lymphocytes incubated with $0.5 \mathrm{mM}$ acetylsalicylic acid exhibited reduced capacity to bind to measles virus-infected $\mathrm{HEp}-2$ cells. The mean \pm SEM percent positive $\mathrm{HEp}-2$ cell adherence for acetylsalicylic acid-treated MS lymphocytes (14.1 $\pm 2.6)$ was significantly different $(P<0.01)$ from the value $(55.2 \pm 2.3)$ for untreated cells. The effect of acetylsalicylic acid was dose-dependent $(0.5 \mathrm{mM}-0.5$ nM) (data not shown). Acetylsalicylic acid had no significant effect on adherence of normal lymphocytes. Similar results were obtained when mononuclear cells were incubated with $30 \mu \mathrm{M}$ indomethacin (Table I). Acetylsalicylic acid did not alter the binding of MS or control lymphocytes to uninfected HEp-2 cells.

Effect of aspirin (in vivo) on lymphocyte adherence. Adherence of MS lymphocytes to measles virus-infected HEp-2 cells was reduced significantly after patients were treated with therapeutic (anti-inflammatory) doses of aspirin for $2 \mathrm{~d}$ (Table II). The mean \pm SEM
TABLE I

Lymphocyte Adherence to Measles Virus-Infected HEp-2 Cells: Effect of Acetylsalicylic Acid and Indomethacin (In Vitro)*

\begin{tabular}{lccc}
\hline & $\begin{array}{c}\text { No. of } \\
\text { donors }\end{array}$ & $\begin{array}{c}\text { Untreated } \\
\text { lymphocyte } \\
\text { adherence }\end{array}$ & $\begin{array}{c}\text { Treated } \\
\text { lymphocyte } \\
\text { adherence }\end{array}$ \\
\hline $\begin{array}{l}\text { Acetylsalicylic acid } \\
\quad \text { MS patients }\end{array}$ & 7 & $55.2 \pm 2.3$ & $14.1 \pm 2.6 \S$ \\
$\quad \begin{array}{l}\text { Controls } \\
\text { Indomethacin }\end{array}$ & 4 & $24.0 \pm 2.9$ & $16.2 \pm 2.9^{\text {II }}$ \\
$\quad$ MS patients & 5 & $61.9 \pm 2.4$ & $24.5 \pm 2.7 \S$ \\
\hline
\end{tabular}

* Mononuclear cells incubated with $0.5 \mathrm{mM}$ acetylsalicylic acid or $30 \mu \mathrm{M}$ indomethacin $\left(15 \mathrm{~min}\right.$ at $\left.37^{\circ} \mathrm{C}\right)$.

$\$$ Values are mean \pm SEM.

$\$$ Significantly different from untreated values $(P<0.01$; Student's $t$ test).

"Not significantly different from untreated control cells $(P>0.05)$.

for the LAD after aspirin treatment was $27.0 \pm 2.1 \%$ for MS patients, a value significantly different from the mean \pm SEM $(60.8 \pm 2.6 \%)$ observed before aspirin treatment. No further decrease in the LAD was seen with continued ingestion of aspirin for two to three more days (data not shown). Values returned to normal within $24-48 \mathrm{~h}$ even after $5 \mathrm{~d}$ of treatment. Aspirin ingestion had no significant effect on adherence of lymphocytes from normal control donors.

The effect on lymphocyte adherence of a single dose of aspirin was examined. LAD were performed on healthy volunteers and MS patients at intervals after ingestion of $1.3 \mathrm{~g}, 975 \mathrm{mg}, 650 \mathrm{mg}$, and $325 \mathrm{mg}$ of aspirin. Results of experiments performed on MS patients are shown in Fig. 1. A single dose of $325 \mathrm{mg}$

TABLE II

Lymphocyte Adherence to Measles Virus-Infected HEp-2 Cells: Effect of Aspirin (In Vivo)*

\begin{tabular}{lccr}
\hline & $\begin{array}{c}\text { No. of } \\
\text { donors }\end{array}$ & $\begin{array}{c}\text { Lymphocyte } \\
\text { adherence }\end{array}$ & $\begin{array}{c}\text { Serum } \\
\text { salicylate }\end{array}$ \\
\hline MS & & $\%$ & $m g / d l$ \\
$\quad$ Before aspirin & 7 & $60.8 \pm 2.6$ & $2.9 \pm 1.2$ \\
$\quad$ After aspirin & 7 & $27.0 \pm 1.5 \S$ & $18.8 \pm 2.7$ \\
$\begin{array}{l}\text { Controls } \\
\text { Before aspirin }\end{array}$ & 3 & $32.0 \pm 1.6$ & $1.7 \pm 1.0$ \\
After aspirin & 3 & $25.6 \pm 1.9$ & $25.4 \pm 2.3$ \\
\hline
\end{tabular}

* Patients took $1 \mathrm{~g}$ aspirin four times daily. Lymphocyte adherence determined before and 10-12 h after final dose.

$\ddagger$ Mean \pm SEM.

$\$$ Significantly different from untreated values $(P<0.01$; student's $t$ test). 


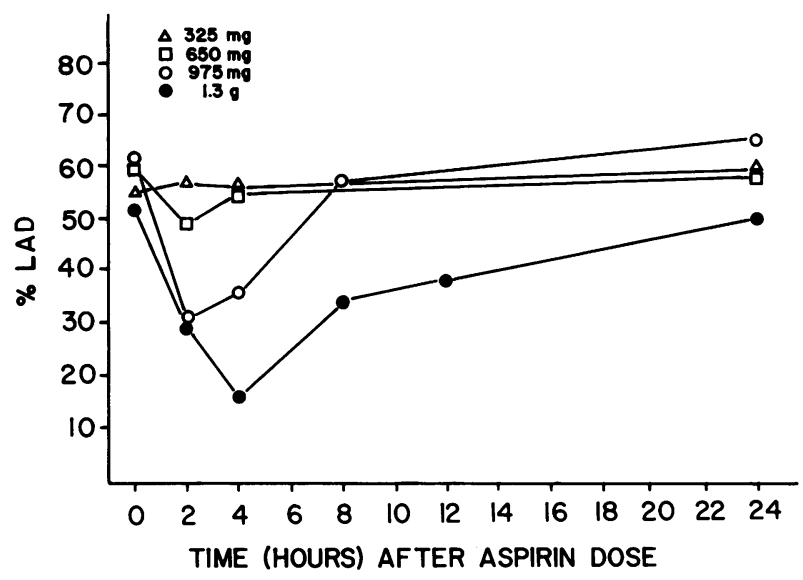

Figure 1 The effect of single doses (325 mg-1.3 g) of aspirin on the LAD of MS patients. Blood samples were drawn before and at intervals up to $24 \mathrm{~h}$ after aspirin ingestion. Points on the curves represent the mean for experiments performed on three patients at each dose of aspirin studied.

aspirin had no effect on lymphocyte adherence. A dose of $650 \mathrm{mg}$ produced consistent but statistically insignificant decreases in the LAD. Single doses of $975 \mathrm{mg}$ of $1.3 \mathrm{~g}$ reduced LAD values significantly $(P$ $<0.01)$. LAD values were significantly reduced at 2 and 4-h after a single 975-mg dose and returned to preingestion values by $8 \mathrm{~h}$. Single doses of $1.3 \mathrm{~g}$ were most effective, significantly $(P<0.01)$ reducing LAD for up to $12 \mathrm{~h}$. Aspirin ingestion had no significant effect on control LAD.

Aspirin- (in vitro and in vivo) induced reduction of lymphocyte adherence was associated with inhibition of prostaglandin synthesis by mononuclear cells in tissue culture (data not shown).

\section{DISCUSSION}

Peripheral blood lymphocytes from patients with MS adhere to measles virus-infected HEp-2 cells in significantly greater numbers than lymphocytes from controls $(1,2)$. The addition to normal lymphocytes of low concentrations of prostaglandin $E_{1}(10 \mathrm{nM})$ increases adherence to MS levels $(3,8)$. The results presented here provide evidence that ingestion of aspirin ( $>650 \mathrm{mg}$ ) by MS patients results in a significant reduction in lymphocyte adherence. Direct addition of aspirin or indomethacin to MS mononuclear cells in vitro also reduces lymphocyte adherence to normal levels in a dose-dependent fashion.

A single dose of $325 \mathrm{mg}$ aspirin, which is sufficient to inhibit platelet cyclooxygenase for $2 \mathrm{~d}$ (9), had no effect on the LAD. These results suggest that inhibition of mononuclear cell rather than platelet cyclooxygenase contributes to the reduction in LAD. Evi- dence does exist (10) that the cyclooxygenase in other tissue is more resistant to aspirin than the platelet enzyme. Thus, the dose which is necessary to inhibit prostaglandin synthesis in different tissues can vary from $325 \mathrm{mg}$ to $7 \mathrm{~g} / \mathrm{d}$ (11-13). Aspirin treatment of control mononuclear cells in vitro, or ingestion of aspirin by healthy volunteers, reduces lymphocyte adherence only slightly even though prostaglandin synthesis by these cells is also almost completely inhibited. In all studies, inhibition of prostaglandin synthesis in MS cells reduced the LAD to control levels but did not completely inhibit the binding of lymphocytes to measles virus-infected cells. These observations suggest that attachment of normal lymphocytes to measles virus-infected cells is not entirely dependent upon prostaglandin synthesis, but a prostaglandin-mediated event may account for the increased adherence to measles virus-infected cells exhibited by MS lymphocytes.

Prostaglandins may alter cell-surface topography such that more lymphocytes express the receptor necessary for their attachment to measles virusinfected cells. This potential capability is suggested by the observation (14) that prostaglandin $\mathrm{E}_{1}$ can increase theta antigen expression on the surface of lymphocytes from thymectomized mice.

It is not known whether the lymphocyte adherence determination will be useful in evaluation of patients with possible MS; initial experience with it suggests that in some circumstances its use may facilitate diagnosis (2). It is clear from the studies presented here that the influence of inhibitors of prostaglandin synthesis must be considered when the LAD is performed. In any event, better understanding of the mechanisms responsible for the abnormal cell-cell interactions exhibited by lymphocytes from MS patients should provide useful insights into the pathogenesis of MS.

\section{ACKNOWLEDGMENTS}

We appreciate the expert technical assistance of Barbara $\mathrm{L}$. Rothman, Virginia Geortz, and Tracey Stephen Koff, and we thank Nancy Rothman and the Connecticut Valley Chapter of the National Multiple Sclerosis Society for their cooperation.

This study was supported by National Institutes of Health grant AM 17309, a grant from the National Multiple Sclerosis Society, and a grant from the Kroc Foundation.

\section{REFERENCES}

1. Levy, N. L., P. S. Auerbach, and E. C. Hayes. 1976. A blood test for multiple sclerosis based on the adherence of lymphocytes to measles-infected cells. N. Engl.J. Med. 294: 1423-1427.

2. Dore-Duffy, P., R. B. Zurier, J. Donaldson, S. S. Nystrom, M. V. Viola, B. Rothman, and H. G. Thompson. 1979. 
Lymphocyte adherence in multiple sclerosis. Neurology. In press.

3. Zurier, R. B., P. Dore-Duffy, and M. V. Viola. 1977. Adherence of human peripheral blood lymphocytes to measles infected cells. Enhancement by prostaglandin $\mathrm{E}_{1}$. N. Engl. J. Med. 296: 1443-1446.

4. Schumacher, G. A., G. Beebe, R. F. Kilber, L. T. Kurland, J. F. Kurtze, F. McDowell, B. Nagler, W. A. Silbey, W. W. Tourtellotte, and T. L. William. 1965. Problems of experimental trials of therapy in multiple sclerosis: reported by the panel on evaluation of therapy in MS. Ann. N. Y. Acad. Sci. 122: 552-568.

5. Böyum, A. 1974. Separation of blood leukocytes, granulocytes and lymphocytes. Tissue Antigens. 4: 269-274.

6. Ehrnst, A., L. Weiner, and E. Norrby. 1974. Fluctuations and distribution of measles virus antigens on chronically infected cells. Nature (Lond.). 248: 269-273.

7. Natelson, S. 1957. Microtechniques of Clinical Chemistry for the Routine Laboratory. Charles C. Thomas, Publisher, Springfield, Ill. 332.

8. Dore-Duffy, P., and R. B. Zurier. 1978. Lymphocyte adherence to measles infected cells. Effect of prostaglandins, cyclic nucleotides and colchicine. Fed. Proc. 37: 1746. (Abstr.)
9. Burch, J. W., N. Stanford, and P. W. Majerus. 1978. Inhibition of platelet prostaglandin synthetase by oral aspirin. J. Clin. Invest. 61: 314-319.

10. Majerus, P. W., and N. Stanford. 1977. Comparative effects of aspirin and diflunisal on prostaglandin synthetase from human platelets and sheep seminal vesicles. Br. J. Clin. Pharmacol. 4: 155-185.

11. Halushka, P. V., H. B. Daniell, W. L. Miller, Jr., and H. Thiboudeaux. 1977. Increased coronary sinus prostaglandin E-like material (iPGE) during myocardial infarction (MI): beneficial effects of aspirin (ASA). Clin. Res. 25: 225A. (Abstr.)

12. Patrono, C., G. Ciabattoni, F. Greco, and D. GrossiBelloni. 1976. Comparative evaluation of the inhibitory effects of aspirin-like drugs on prostaglandin production by human platelets and synovial tissue. Adv. Prostaglandin Thromboxane Res. 1: 125-131.

13. Horton, E. W., R. L., Jones, and C. G. Marr. 1973. Effects of aspirin on prostaglandin and fructose levels in human semen. J. Reprod. Fertil. 33: 385-392.

14. Bach, M-A., C. Fournier, and J. F. Bach. 1975. Regulation of $\theta$-antigen expression by agents altering cyclic AMP levels and by thymic factor. Ann. N. Y. Acad. Sci. 249: 316-327. 